\section{Social network influences on employee responses to organizational withdrawals}

\section{Social network influences on employee}

\author{
Frank Siedlok
}

University of Auckland, Auckland, New Zealand

Paul Hibbert

University of St. Andrews, St. Andrews, UK, and

Fiona Whitehurst

Newcastle University, Newcastle upon Tyne, UK
Received 31 January 2018 Revised 26 September 2019 Accepted 7 November 2019

\begin{abstract}
Purpose - The purpose of this paper is to develop a more detailed understanding of how embedding in different social networks relates to different types of action that individuals choose in the context of organizational closures, downsizing or relocations. To develop such insights, this paper focuses on three particular types of social networks, namely, intra-organizational; external professional and local community networks. These three types of networks have been frequently related to different types of action in the context of closures and relocations.

Design/methodology/approach - This is a conceptual paper. The authors develop the argument by integrating relevant recent literature on the salience related to embedding in different types of social networks, with a particular focus on responses to organizational closure or relocation.

Findings - The authors argue that at times of industrial decline and closure: embeddedness in intraorganizational networks can favor collective direct action; embeddedness in professional networks is likely to favor individual direct action and embeddedness in community networks can lead to individual indirect action. The authors then add nuance to the argument by considering a range of complicating factors that can constrain or enable the course (s) of action favored by particular combinations of network influences.

Originality/value - On a theoretical level, this paper adds to understandings of the role of network embeddedness in influencing individual and collective responses to such disruptive events; and direct or indirect forms of response. On a practical level, the authors contribute to understandings about how the employment landscape may evolve in regions affected by organizational demise, and how policymakers may study with or through network influences to develop more responsible downsizing approaches.
\end{abstract}

Keywords Social networks, Employment, Embeddedness, Embedding, Organizational demise, Community

Paper type Conceptual paper

\section{Introduction}

Closures, downsizing and relocations are a perennial problem affecting both advanced economies and newly industrialized nations (Bentley, Bailey \& Ruyter, 2010;

(C) Frank Siedlok, Paul Hibbert and Fiona Whitehurst. Published in Organization Management Journal. Published by Emerald Publishing Limited. This article is published under the Creative Commons Attribution (CC BY 4.0) licence. Anyone may reproduce, distribute, translate and create derivative works of this article (for both commercial and non-commercial purposes), subject to full attribution to the original publication and authors. The full terms of this licence may be seen at http:// creativecommons.org/licences/by/4.0/legalcode

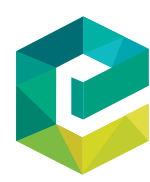

Organization Management Journal Vol. 17 No. 1,2020 pp. $15-35$ Emerald Publishing Limited DOI 10.1108/OMJ-01-2018-0498 
OMJ

17,1

Datta, Guthrie, Basuil \& Pandey, 2010; Hassink \& Shin, 2005; Minchin, 2009). Besides, such organizational withdrawals are increasingly affecting skilled (professional) as much as unskilled workers (Arntz, Gregory \& Zierahn, 2016; Hartley, 2017). Understanding how individuals may respond to these difficult situations, individually or collectively, is important to organizations wishing to undertake "responsible downsizing." In addition, policymakers need to understand how local networks support alternative employment options, as studies have shown that social networks can influence how individuals choose to act (Delgado-Márquez, Hurtado-Torres, Pedauga \& Cordón-Pozo, 2018; Hayton, Carnabuci \& Eisenberger, 2012; Ng \& Feldman, 2012; Porac, Thomas \& Badden-Fuller, 2011). However, the particular influences of different kinds of networks on individual action, and how these influences may interact, are not clearly conceptualized in the literature. Consequently, in this paper, we focus on developing a conceptual understanding of the relationship between the influence of individual embedding within multiple kinds of network, and the different actions individuals take in the context of organizational demise or relocation.

The concept of embeddedness helps to explain how actors, both individuals and organizations, are socially situated within an array of interpersonal and professional ties (Delgado-Márquez et al., 2018; Moran, 2005; Provan, Huang \& Milward, 2009; Smith \& Stevens, 2010), which, in turn, can provide access to a range of resources of a financial, informational, emotional or political nature (Batjargal, 2003; Berends, van Burg \& van Raaij, 2010; Biniari, 2012; Hayton, Carnabuci \& Eisenberger, 2012; Kistruck \& Beamish, 2010). The literature clearly demonstrates that access to such resources, and the support that embedding in different networks offers, can enable or constrain different forms of action (Batjargal, 2003; Jack \& Anderson, 2002; Uzzi, 1997) and influence career choices of individuals (Anteby, Chan \& DiBenigno, 2016; Avnimelech \& Feldman, 2010; Dany, Louvel $\&$ Valette, 2011). These influences are especially significant in the context of organizational instability and, in particular, closure or relocation decisions that often affect a large number of individuals, as they can provide resources for responsive action. For example, the literature suggests that individuals: might draw on the resources offered by local social networks to engage in a range of entrepreneurial activities (Benneworth, 2004); they might mobilize the resources offered by the organizational network and attempt to preserve the organization (Jaumier, 2016); or leveraging their professional networks, they might pursue potential job opportunities elsewhere (Leppäaho, Chetty \& Dimitratos, 2018; Villadsen, 2011). Furthermore, reports and news coverage suggest that at times of closures or when relocation decisions are made, employees refuse to relocate with the company or might reject job opportunities elsewhere and instead are more likely to seek to create job opportunities locally (Whitehurst, Siedlok, \& Race, 2008; Whitehurst \& Siedlok, 2006).

Yet, despite the mounting evidence that actions in response to industrial demise and relocations are affected by the different kinds of opportunities and influences afforded by particular network connections (Davis, Renzulli, \& Aldrich, 2006; Gardiner, Stuart, MacKenzie, Greenwood, \& Perrett, 2009; Porac, Thomas \& Badden-Fuller, 2011; Strangleman, 2001), the literature has paid significantly less attention to the distinctive characteristics of different kinds of networks and how these relate to their enabling and constraining effects (Batjargal, 2003; Kalantaridis \& Bika, 2006). Similarly, there has been little attention to the relative salience and influence of different networks (Rodrigues \& Guest, 2010; Tasselli, 2015) on both individuals and groups and how such influences operate when they may "pull" in different directions. For example, Frenkel (2003) questions whether the multiple allegiances of workers to an organization, professional associations and trade unions benefit or damage organizations, while Tasselli's (2015) study on the dynamics of 
knowledge transfer in healthcare suggests that multiple allegiances impact on individuals' opportunities for decision-making and action.

Thus, to develop more detailed insights into the influence of social networks on individuals and their contexts, it is important to, first, acknowledge that individuals are simultaneously embedded within a range of networks (Granovetter, 1985; Hess, 2004; Jack \& Anderson, 2002), second, to consider how different types of network context can have subtly different influences and, third, to consider the interaction of these effects. Indeed, as Roos (2018) infers from her work on gender and entrepreneurship, understanding embeddedness

Social network influences on employee in social networks helps us to understand how different contexts interact, providing a more nuanced explanation of the interplay of individual decisions and the networks that an actor is a part of.

To develop such insights, this paper focuses on network types that are well-characterized in the literature, in contextual settings that have the potential to make their influences amplified and clearer to observe. Consequently, in this paper, we consider three kinds of well-characterized social networks, namely, intra-organizational; external professional; and local community networks. These three types of networks have been frequently related to different types of action in the context of closures and relocations (Delgado-Márquez et al., 2018; Hayton, Carnabuci \& Eisenberger, 2012; Ng \& Feldman, 2012; Porac, Thomas \& Badden-Fuller, 2011). We focus on these kinds of networks in the context of organizational closures, downsizing or relocations as these kinds of withdrawal have significant effects on individuals and the networks they are embedded in. Furthermore, this context is itself an important practical problem for which our theoretical insights can both be developed and may be useful. In particular, the argument developed in the paper can help organizations and policymakers in developing interventions to industrial decline and closure that are aligned with the particular context and utilizing the multiple embeddedness of those affected. Indeed, this can help to develop more responsible downsizing approaches.

Accordingly, the remainder of this paper is structured as follows. First, we provide a definition and an overview of embeddedness, by selecting and integrating relevant recent literature that addresses variations in different kinds of social networks, with a particular focus on responses to organizational closure or relocation. Based on these insights we go on to develop our literature-grounded argument to show how at times of industrial decline and organizational closure: embeddedness in intra-organizational networks can favor collective direct action; embeddedness in professional networks is likely to favor individual direct action and embeddedness in community networks can lead to individual indirect action. We then consider the interactions and relative "strength" of these influences, before going on to consider complicating factors that can constrain or enable the course (s) of action favored by particular combinations of network influences. We bring our argument together in a concluding section that includes a summary of the theoretical and practical contributions of the paper. On a practical level, we contribute to understandings about how the employment landscape may evolve in regions affected by organizational demise, and how policymakers may work with or through network influences. On a theoretical level, this article adds to understandings of the role of network embeddedness in influencing individual and collective responses to such disruptive events; and direct or indirect forms of response.

\section{Embeddedness in social networks: influential ties}

Social networks are distinct from the other two main forms of economic organization (Kilduff \& Brass, 2010; Powell, 1990), namely, markets, organized through transactions and hierarchies, organized through command structures. Networks are instead organized through embedded relationships. Embeddedness is a multidimensional concept describing 
OMJ

17,1

18

social relationships, which has been treated in various ways in the literature. The key four dimensions of embedded relationships can be summarized as follows:

(1) they develop, and gain their strength, from the frequency of interactions, which result in;

(2) pro-social behaviors leading to;

(3) resource sharing and expectations of reciprocity; and so

(4) they constitute an array of interpersonal ties, which provide the structure of social networks, that "close the loop" by influencing actors' behaviors, decisions and ability to act.

The first aspect of embedded relationships, frequency of interaction, has been directly associated with the strength of social networks (Moran, 2005; Provan et al., 2009; Smith \& Stevens, 2010). This is because greater embeddedness is frequently associated with the development of strong ties, which arise through frequent interaction (Kilduff \& Brass, 2010).

However, the literature also opens up the mechanisms behind the formation and strength of embedded relationships through a focus on the second aspect, the pro-social behaviors, which support the development of relationships in networks such as friendship, advice, discussion and trust (Kilduff \& Brass, 2010; Tasselli, 2015). These pro-social behaviors lead to durable relationship ties through the third aspect - an expectation of reciprocity (Kilduff $\&$ Brass, 2010; Tasselli, 2015) and access to resources. These resources can be of great importance to individuals and can be informational, cognitive, cultural, political or emotional (Batjargal, 2003; Berends, van Burg \& van Raaij, 2010; Biniari, 2012; Hayton, Carnabuci \& Eisenberger, 2012; Kistruck \& Beamish, 2010).

- The formation of an array of ties leads to the fourth aspect, in which the individual's behaviors and decisions are shaped by the these relationship (Chajewski, 2007; Kilduff \& Brass, 2010; Roos, 2018) while, at the same time, these behaviors shape the networks within which they are embedded (Halbesleben \& Wheeler, 2008; Tasselli, 2015). The influences on the individual received in this way affect the possible course (s) of action that they may consider to be appropriate (Akkerman, Born \& Torenvlied, 2013; Sydow, Lindkvist \& DeFillippi, 2004, p. 1479). Thus, embeddedness, overall, describes the more-or-less durable and situated nature of the relationships, which constitute social networks.

Embedded relationships, developed as described above, can vary in strength over time, sometimes leading to unexpected positive benefits. For example, weak or dormant ties can provide access to important resources. As Granovetter (1973, p. 1372) notes: "It is remarkable that people receive crucial information from individuals whose very existence they have forgotten." However, the effects of embedding can be constraining and enabling. For example, embeddedness and the processes of embedding can lead to high levels of association (over-association) with a given group and/or tensions arising from multiple affiliations (Husted \& Michailova, 2010; Tasselli, 2015). Therefore, embeddedness illuminates how constraining and enabling influences are provided by social networks and may shed light on the apparently non-rational economic behaviors that individuals take to remain within their networks (Roos, 2018; Tasselli, 2015). However, while the nature of embedding and its constraining and enabling effects - in general - are well-characterized, there is a need for further attention to the influence of social networks on individuals concerning their decisions and actions. 
To provide a revealing view on the dynamics of social network influence, we focus on a context in which individuals might otherwise be presumed likely to act in their personal economic interest, namely, organizational closures and relocations affecting a workforce. As we outlined in the introduction, there are three types of networks have been wellcharacterized in the literature and can be related to different types of action in the context of closures and relocations, namely, intra-organizational; professional; and local community networks (Delgado-Márquez et al., 2018; Hayton, Carnabuci \& Eisenberger, 2012; Ng \& Feldman, 2012; Porac, Thomas \& Badden-Fuller, 2011). We review the key arguments in the extant literature on the effects of embedding in each of the three kinds of networks below. However, we do acknowledge that the boundaries might sometimes be blurred (for example, Gardiner et al., 2009; MacKenzie, Stuart, Forde, Greenwood, Gardiner \& Perrett, 2006).

\section{Embedding in internal, intra-organizational social networks}

The embedding of individuals in social networks within organizations is argued to have significant effects, namely, it increases perceptions of organizational support, boosts social attachment and lessens the likelihood of individuals seeking alternative employment, even when job insecurity is perceived to be high (Crossley, Bennett, Jex \& Burnfield, 2007; Felps, Mitchell, Hekman, Lee, Holtom \& Harman., 2009; Hayton, Carnabuci \& Eisenberger, 2012; Murphy, Burton, Henagan \& Briscoe., 2013). Employees, thus, find security through embedding within a stable organizational setting. Partly for those reasons, embeddedness in intra-organizational networks is associated with the development of trust and camaraderie; this, in turn, supports individual career progress and provides informal support for organizational aims at the same time (Burby, 2003; Lee \& Kim, 2011).

In addition to the impact on individual capabilities for career progression, internal social networks support important organizational capabilities (Kilduff \& Brass, 2010). In particular, social networks "make the social fabric of organizations more (or less) effective in creating and transferring knowledge" (Levin \& Cross, 2004, p. 1487), impacting the processes of knowledge "transfer" and "creation" (Hsiao, Tsai \& Lee, 2006; Manning, 2010). Furthermore, embeddedness in intra-organizational networks has been associated with allegiance-related tensions when individuals are exposed to external partners or networks (Clark, 2004; Husted \& Michailova, 2010). Such tensions can arise between internal and external connections because the organizational setting is recognized as providing important structure and meaning for employees (Clark, 2004; Davis, 2003; Parry, 2003). However, such tensions are not necessarily entirely negative. Both Akkerman, Born \& Torenvlied (2013) and Mohrman Tenkasi and Mohrman (2003) show that social networks are important as both influencers and outputs of organizational change processes, whether in moderating participation in collective action or whether members will conform to the intended designs or will pursue more creative and more effective actions (Mohrman Tenkasi \& Mohrman, 2003, p. 321) through leveraging resources connected to external networks. Similarly, the trust underpinned by embedded social networks allows change agents to have an impact within organizations; for example, Biniari (2012) found that intra-organizational envy of corporate entrepreneurs is lessened in contexts of high social embeddedness, which means they are more likely to act. Indeed, intra-organizational networks are generally considered to be enablers of (internal) entrepreneurial action (Kelley, Peters \& O'Connor, 2009).

Summarizing the discussion above, it is clear that the embeddedness of individuals within intra-organizational social networks is important in three ways. First, this embeddedness facilitates individual progress within an organization. Second, it provides support for certain organizational capabilities, including performance, collaboration, 
OMJ 17,1

learning and innovation implementation. Third, it influences the organization's deliberate and emergent patterns of change over time, which can be related to the entrepreneurial activities of individuals. This means that the embedding of individuals within intraorganizational networks will also enable particular responses in times of decline and closure. While the most obvious is a collective action such as strikes, to preserve the status quo (Akkerman, Born \& Torenvlied, 2013), in other cases strong intra-organizational embedding can lead to a more positive type of action. It can be argued that, at times of organizational turnover, there is a window of opportunity in which the capabilities and influence of a tightknit intra-organizational network, leveraging their potential as change agents and internal entrepreneurs (Akkerman, Born \& Torenvlied, 2013; Ashforth \& Reingen, 2014; Jaumier, 2016) might potentiate cooperation in direct action such as employee or management buyouts or attempts at restructuring undertaken by the majority of the organization (given access to suitable funding resources, support and capabilities - as we will discuss in more detail later).

Furthermore, indirect evidence suggests that managers of internal buyouts treat their workers rather differently than managers from external acquirers. Specifically, there is evidence of a positive attitude toward members of the (former) organization in Bacon Wright and Demina (2004) study, which found that in times of turbulence, organizations formed through internal management buyouts focused on the abilities of organization members (and invested in these) to aid survival, rather than relying on cost-cutting through reducing the workforce. While Wright, Hoskisson and Busenitz (2001, p. 118) point out that some managers, rather than leaving to start a venture, preferred to remain until an opportunity for a buyout emerged, Jaumier (2016) shows that such buy-outs are often characterized by high levels of sacrifice and commitment from both employees and management. This is important as management buyouts are believed to enable innovation and growth of otherwise ineffective (parts of) organizations, but the commitment of managers to these new organizations has been argued to be essential to the realization of such expectations (Whitehurst, Siedlok, \& Race, 2008). Such patterns of trust in the development of human capital are consistent with the existence of underlying social networks in these contexts (Felps et al., 2009; Hayton, Carnabuci \& Eisenberger, 2012); by supporting trust, these social networks also provide an appealing context for the entrepreneurial orientation and proactivity of some members (Benneworth, 2004; Parry, 2003). Thus, overall, the influence of intra-organizational social networks can help to explain the likely formation of management buyouts and their potential to endure, especially in difficult conditions.

However, it may be the case that there is no access to funding and support for a buyout or the business proposition may be unviable due to exogenous factors. In such cases, network members will be motivated toward collective resistance and lobbying. This kind of outcome is exemplified by collective action to raise worker visibility such as protests and battles against closure decisions (Akkerman, Born \& Torenvlied, 2013; Savage, 2004) or internal coalitions of management opposing such changes (Clark, 2004).

Overall, other things being equal, the strong embedding of employees in intraorganizational networks is likely to support collective direct action of some form to preserve or attempt to preserve (at least some part of) the organization when a closure is imminent. By collective action, we mean action that is undertaken by the existing network, or part of it, in an attempt to preserve the social structure of embedded relationships for those individuals. For the organization's management (if they are responsibly-oriented) and policymakers the crucial task is to ensure that access to needed resources and the development of relevant capabilities is supported (Whitehurst, Siedlok, \& Race, 2008) to encourage collective action beyond resistance. Relevant resources and capabilities might be 
provided through access to finance and exposure to relevant entrepreneurial skills and role models to encourage management or employee buy-out.

\section{Embedding in external professional social networks}

External professional social networks are important in relation to individual career potential and organizational arrangements in two chief ways. First, relational connections between individuals can provide access to resources, which, in turn, can increase individuals' professional mobility (Anteby, Chan \& DiBenigno, 2016; Lin, Ensel \& Vaughn, 1981; van Rijnsoever, Hessels \& Vandeberg, 2008), even when these connections remain dormant (Granovetter, 1973). Indeed, allowing connections to become dormant and then re-connecting is efficient, and provides access to knowledge and experience (Levin et al., 2011). Moreover:

[...] when people reconnect, they still have feelings of trust and a shared perspective - which are critical for receiving valuable knowledge from someone - and our research shows that these feelings do not fade much, if at all (p. 47).

Thus, extra-organizational professional connections may be strategically useful for individuals (Batjargal, 2003; Manning, 2010); but the information provided through these channels may also be valuable to organizations (Berends, van Burg \& van Raaij, 2010; Engeström, 2006; c.f. Granovetter, 1985).

Second, the innovative potential and competencies of organizations are enhanced by individuals' participation in professional social networks (Ciabuschi, Dellestrand \& Martín, 2011; Collinson \& Wang, 2012), as individuals have better access to knowledge in this way. Such access to knowledge arises because collaborative participation in professional social networks leads to opportunities for learning and:

[...] highly embedded participants experience exposure to more knowledge and can accumulate knowledge faster. Furthermore, variations in the quality of the knowledge exchanged can be expected to vary with the level of embeddedness so that well-embedded participants will have access to higher-quality knowledge. (Andersen, 2013, p. 146; see also Geletkanycz \& Boyd, 2011).

Better sources of knowledge may enable organizations, through embedded key individuals, to act as "institutional entrepreneurs" (Lawrence, Hardy \& Phillips, 2002), who can use "global pipelines" to find and act on emerging opportunities elsewhere (Bathelt, Malmberg \& Maskell, 2004). Thus, "networked knowledge" also has the spin-off benefit of providing some influence on the evolution of fields and regional centers. However, Parrilli (2009) has identified traditions of collective association that pre-date professional arrangements, which, perhaps, explains why the decisions of highly embedded professionals may not only shape their local context but also be influenced by long-established extra-organizational professional networks (Villadsen, 2011). In the increasingly professionalized world, it is often professional rather than organizational affiliations that can provide a stronger steer to individual career choices (von Nordenflycht, 2010).

The relationship between professional network embeddedness and career mobility is, however, often not straightforward, as there are countervailing effects. That is, an individual's position in a professional network is often closely tied to membership in a particular organization. Furthermore, once an individual has become embedded in professional social networks that provide them with a sense of supportive solidarity (Zhang, 2010) - in the institutional and societal context in which their work is recognized - their independence is constrained at the same time as their influence and impact is enabled (Battilana, 2006; Kilduff \& Brass, 2010). These enabling-and-constraining embedding
Social network influences on employee 
OMJ 17,1

effects, therefore, somewhat link individuals to a particular local context and a less geographically-bounded professional network (Clark, 2004).

In general, the embedding of individuals within professional social networks supports the exploitation of connections in times of need such as instances of organizational turbulence, decline and closure. Such professional networks can provide individuals with new opportunities for finding employment, as employees are likely to be known to professional or occupational peers and managers of other firms (Anteby, Chan \& DiBenigno, 2016; Granovetter, 1985). In this kind of situation, it is expected that a troubled region will experience an exodus of professionals, who may be willing to take advantage of opportunities wherever they may be found.

However, whether this direct action involves exit from the region or alternative local entrepreneurship (leveraging professional network resources more directly), is dependent on the sense of connection to a local community. Professional networks may provide the necessary resources, contacts and, in some cases, become contractual templates (Berends, van Burg \& van Raaij, 2010; Leppäaho et al., 2018; Nyström, 2018), but this may only be a more attractive option when family factors and embedded ties to local community are at risk of being affected. Indeed, there is a mounting evidence that family and community networks can produce tensions for individuals seeking professional advancement within and across geographical boundaries (Feldman \& Ng, 2007; Valette \& Culié, 2015) as individuals often consider how their career decisions might affect their family and friends (Fletcher \& Bailyn, 1996; Howes \& Goodman-Delahunty, 2014; Ituma \& Simpson, 2009).

Local community and family ties can, therefore, influence how individuals are (or become) embedded in both their professions and their geographical contexts (Feldman \& Ng, 2007; Rodrigues, Guest \& Budjanovcanin, 2016; Valette \& Culié, 2015) and are enabled and constrained in their choices of employment action by these influences. This is consistent with Hochner and Granrose's (1985) study, which found that some belief in collective ideals was associated with entrepreneurial intentions among workers in times of redundancy. We discuss the effects of embedding in local community networks in the next section.

Overall, other things being equal, strong embedding in external professional networks is likely to support individual direct action; individuals are likely to leverage network resources, either to access new employment opportunities within the network or to engage in entrepreneurial activities.

\section{External, local community networks}

Beyond organizational and professional networks, individuals are embedded in family and community social networks, which may include or encompass members of voluntary organizations, local communities, interest groups, churches or schools (Bailey et al., 2012; Boschma and Lambooy, 1999; Mitchell et al., 2001; Ng \& Feldman, 2012). Extraorganizational networks of these kinds can provide considerable social and personal fulfillment, support and the necessary structure and new routines, which individuals feel the need for during and after the loss of organizational structures (MacKenzie et al., 2006; Parry, 2003; Strangleman, 2001). This is because local community networks can provide support during the unsettling times of closures (MacKenzie et al., 2006) by providing opportunities to replace the lost routines in individuals' lives with regular patterns of social interactions in non-organizational contexts (Strangleman, 2001). Thus, local community embeddedness is often found to be more salient during decisions related to career-upsetting events (Whitaker, 1986; Whitehurst, Siedlok, \& Race, 2008). More generally, as Parry (2003, p. 237) argues, extra-organizational local networks can provide considerable social and personal fulfillment after the loss of organizational structures and networks. 
There is also evidence that community social networks have professional effects. For example, embeddedness in local community networks has been identified as a component of general job embeddedness (Bailey, Chapain \& de Ruyter, 2012; Clark, 2004; Felps et al., 2009). As such, it has been identified as an important factor in limiting employee turnover, and thus, indirectly facilitating skills development through the retention of experienced employees who can guide informal projects and provide mentoring (Lowe, Hagan \& Iskander, 2010). Furthermore, social settings and groups can help individuals to connect with communities to access local information about professional opportunities, which might be off-limits otherwise (Jack \& Anderson, 2002).

Other, more specific employment influences and effects can also be identified. In particular, during closures when changing employment is involuntary, Tomaney et al. (1999) report that embedding in local community networks is the primary factor influencing self-employment. However, where these social networks are very "tight-knit" the embeddedness can be constraining and limit the scope of business developments; entrepreneurial endeavors become focused on small-scale, highly localized employment rather than maximizing the growth potential of new organizations (Wang \& Altinay, 2012).

More generally, in situations of closure where individuals are embedded within community social networks but no other networks, a shift in meaningful activity from work to community interests can be envisaged. Individuals will take (or create) any work that may be available - but only within their particular locality - given that it provides the means for them to continue engagement with their community interest (s) (Gardiner et al., 2009; Strangleman, 2001). Importantly, a local focus need not mean that individuals will be uninterested in progression in alternative employment. This is because the rewards of career success can be invested in their community network interests. It does mean, however, that they will be unlikely to invest in this work as a meaningful profession. Instead, in the absence of any sense of a collective that provides the resources or mutual support to enable action, they are likely to be forced to consider a diverse range of alternative (un)employment options that may arise through external policy interventions or growth in alternative sectors. This often means acceptance of less meaningful employment options, which fail to use individuals' skills and experience, which over time leads to a lack of energetic entrepreneurial activity and a reduction in up-to-date and focused skills in the region - and thus, a lack of dynamism, which prevents the (re-)development of organizations in an industry affected by cyclic decline (Avnimelech \& Feldman, 2010; Benneworth, 2004). Moreover, policy interventions that try to stimulate bottom-up action in underused communities, without paying attention to the nature and history of existing collectivities in a locality, are not likely to be successful (Vollan, 2012). Overall, community social networks tend to drive individuals to act independently in relation to their employment choices and to favor differences in a form (e.g. entrepreneurial, locally limited self-starts) and/or focus (e.g. alternative industries or activities) in their employment-seeking approach.

Hence, embedding in local/community social networks can have a powerful moderating effect on individual action during organizational decline and demise and, consequently, leads individual indirect action to preserve non-economic sources of meaning and value that are more salient to individuals in these networks.

\section{The salience of embedding in different networks during the industrial demise}

There are two levels of preliminary theoretical implications that can be derived from the preceding discussion of the effects of embedding in different kinds of social networks. First, the typology of different kinds of a social network in which individuals may be embedded, and the characterization of the different influences that they bring to bear on and through 
OMJ

17,1

individuals and collectives have not hitherto been explicitly developed. Furthermore, through building on the insights of $\mathrm{Ng}$ and Feldman (2012) and Lo, Wong, Yam and Whitfield (2012), it can be argued that it is important not to rigidly partition intraorganizational social networks from other kinds of network that may have equal (or greater) salience to individuals (Berends, van Burg \& van Raaij, 2010; Rodrigues, Guest \& Budjanovcanin, 2016). Thus, both clarity concerning the distinctiveness and overlap of different kinds of social networks are important in our preceding argument.

Second and most importantly, the preceding section of the paper has shown how different network embedding patterns may lead to different possibilities and choices regarding the nature and location of future work at times of organizational instability, crisis and closure. We have argued that other things being equal, in times of decline and closure, the influence of network embeddedness on work-seeking and creating activities play out in these ways as follows:

- Embeddedness in intra-organizational networks is likely to favor collective direct action, in the form of management buy-outs or mass resistance;

- Embeddedness in professional networks is likely to favor individual direct action, which can either mean an exodus of professional staff or, with appropriate support, entrepreneurial dynamism within a region; and

- Embeddedness in community networks is likely to favor individual indirect action as local interests displace organizational life as a matter of greatest importance, leading to a relatively non-dynamic landscape in the absence of robust policy interventions.

These insights provide a different contribution to the majority of research in this area, which largely focuses on social network effects on the commitment and mobility of individual employees (Felps et al., 2009; Mitchell et al., 2001; Stam, 2007). Before going further in outlining our more detailed implications related to the dynamic nature and interaction of embedding in different types of social networks, we briefly discuss the main moderating and confounding factors that can enable or constrain these influences.

\section{Moderating factors}

The previous discussion highlighted the potential salience of the three types of social networks, in relation to individual or collective action, in the context of industrial withdrawal. However, the literature suggests other factors that also need to be considered alongside the effects of network embedding. In particular, these are access to necessary resources, experience, skills, education, age and current family status (Nyström, 2018). All of these have been associated with an individual or collective action and can have effects on the salience of the three types of networks.

Most significantly, the isolated influences of patterns of embedding are all ceteris paribus conclusions based on the availability of adequate resources, which may have a profound moderating effect on the influence of patterns of networking and thus on potential outcomes (Andrews, Boyne, Meier, O’Toole \& Walker, 2011; Lepak, Smith \& Taylor, 2007, p. 182). For example, entrepreneurial action, including management buyouts (Whitehurst, Siedlok, \& Race, 2008), may not be possible in the absence of access to capital (Kim, Aldrich \& Keister, 2006), appropriate guidance (Murray, Baldwin, Ridgway \& Winder, 2005) and the right mix of education and experience (Davis, 2003; Zissimopoulos \& Karoly, 2007). Similarly, some less "business savvy" employees might depend on local role models and mentors (Avnimelech \& Feldman, 2010; Benneworth, 2004), which constrains their scope for (mobile) individual action. 
Importantly, these resources are often available across all three types of networks that individuals are embedded in Davis et al. (2006), but may differ in scale and scope.

The availability of resources does, however, need to be considered in the context of an evaluation of what the most salient needs for particular individuals are. For individuals with familial ties, the employment status of a spouse and a family context, which includes dependents have also been observed to impact the type of action they might engage in Rodrigues, Guest and Budjanovcanin (2016), Valcour, Bailyn \& Quijada (2007). In times of closure and financial hardship, the more salient the family's needs become, the less important professional ties might become, thus, favoring direct or indirect collective action. Similarly, networks do not offer only positive externalities. Labianca and Brass (2006) have indicated that a small number of negative relationships may exist in social networks within organizations and have disruptive effects. Similarly, Staber (2011) has shown that external social networks are home to competitive and collaborative motivations; through influence levels in the network, they provide mechanisms for individual competition (Andrews, Boyne, Meier, O'Toole \& Walker, 2011). Thus, embedding in social networks may also expose individuals to negative experiences; experiences that make exit from these collective structures a desirable outcome, hindering the potential for collective direct action and favoring mobility or sector shifts.

\section{Interaction effects and tensions}

Furthermore, there are complex interaction effects and possible overlaps between the different kinds of social networks that we have explored here. At the simplest level, it will be apparent that there may often be a high degree of overlap between intra-organizational social networks and community social networks, in terms of their membership. However, $\mathrm{Ng}$ and Feldman (2012) found that their "results suggest that increases in perceptions of organizational and community embeddedness are associated with increases in work-tofamily conflict and family-to-work conflict over time." Thus, it is important to recognize the discrete existence of these two kinds of networks even if these overlap, as they can "pull" in different directions. Lo et al. (2012) added a further degree of complexity when considering expatriate workers; they found complex interactions between the effects of embedding in their organizations and both local and home communities. Both Ng and Feldman's (2012) and Lo et al.'s (2012) work point to potential impacts on an individual's perceived job mobility, which could be especially important at times of industrial decline and closure.

We also recognize that multiple-network effects can be interlinked in complex and pathdependent ways. These kinds of complex interactions can be inferred, for example, in studies of the closure of the British Gas Engineering Research Station in the North-East of England (Whitehurst, Siedlok, \& Race, 2008). These studies did not focus on social networks, but there is an implicit suggestion that organizational embeddedness led employees to attempt a management buy-out in the first instance. When this failed, we infer that some combination of embeddedness in both external professional (pipeline engineering) and the local community networks (the studies reported significant commitment to local, voluntary restoration projects) encouraged later entrepreneurial action and connection to university partners - while discouraging relocation to a new research facility in another region, established by the departing organization. Hence, all three networks were at play here, with different levels of salience at different times.

Besides, different individuals formerly within the closed organization may have different levels of embedding in various networks. The likely situation of various categories of staff manual workers, technical specialists, managers, etc - could be particularly different. Furthermore, where the loss of an organization is associated with a move to a new region 
OMJ

17,1

rather than a collapse, groups of staff may be deliberately relocated, regardless of particular network influences (Maertz \& Griffeth, 2004). Alternatively, former organization members may be associated with several social network "neighborhoods," based on characteristics such as ethnicity and duration of employment (Lawrence, 2011; see also Wang and Altinay, 2012 for particular insights on ethnic community networks), adding a further layer of complexity. Thus, some individuals may be relatively isolated, either through the extraction of groups of colleagues by managerial fiat or because of local cultural or social distinctiveness.

\section{Summary of key theoretical points}

We summarize our argument so far in Table 1 below, illustrating the relationship between embedding in the different network (s) and the preferred mode of action (direct or indirect) and preferred unit of action (individual or collective) that contribute to the shape of responses to organizational turbulence and closure. The two dimensions help to understand how the range of possible responses is influenced by embedding in particular networks and their relative salience, aspects, which have also

\begin{tabular}{|c|c|c|}
\hline Preferred unit of action & Prefe & $\begin{array}{l}\text { rred mode of action } \\
\text { Indirect }\end{array}$ \\
\hline Individual & $\begin{array}{l}\text { Favored by: } \\
\text { Salient embedding in the } \\
\text { professional network (s) } \\
\text { Negative relationships, tensions, } \\
\text { individual isolation } \\
\text { Access to local/extra-local } \\
\text { networks of support (e.g. capital) } \\
\text { Countervailing influences: } \\
\text { Dependency on organizational } \\
\text { status for network position } \\
\text { Salient embedding in the local } \\
\text { community network (s) } \\
\text { Salient embedding in Intra- } \\
\text { Organizational network }\end{array}$ & $\begin{array}{l}\text { Favored by: } \\
\text { Salient embedding in the local community } \\
\text { network (s) } \\
\text { Negative relationships, tensions, individual } \\
\text { isolation } \\
\text { Lacking in access to necessary resources for } \\
\text { direct action } \\
\text { Countervailing influences: } \\
\text { Family needs and other financial pressures } \\
\text { and priorities }\end{array}$ \\
\hline Collective & $\begin{array}{l}\text { Favored by: } \\
\text { Salient embedding in the intra- } \\
\text { organizational network (s) } \\
\text { Available capital, experience and } \\
\text { education to support } \\
\text { entrepreneurial options } \\
\text { Further reinforced by salient } \\
\text { embedding in local community } \\
\text { networks } \\
\text { Countervailing infuences: } \\
\text { Family needs and financial } \\
\text { pressures and priorities } \\
\text { Corporate talent relocation } \\
\text { programs } \\
\text { Salient embedding in/ } \\
\text { identification with the } \\
\text { professional network }\end{array}$ & $\begin{array}{l}\text { Indirect collective actions are not conceptually } \\
\text { plausible, as indirect actions are based on } \\
\text { individual willingness to consider multiple } \\
\text { satisficing outcomes. A collective sense of } \\
\text { purpose or goal is, therefore, extremely unlikely }\end{array}$ \\
\hline
\end{tabular}

\section{Table 1.}

Embedding and other influences on the action in times of organizational closure
Favored by: individual isolation status for network position Salient embedding in the local Favored by: education to support enceurial options networks professional network 
been largely neglected the literature so far (for example, see $\mathrm{Ng} \&$ Feldman, 2012; Nyström, 2018).

Furthermore, the framework captures how certain factors can have a moderating or confounding effect on the main network influences that we have described above. The existence of negative relationship effects, tensions between members of different networks or individual isolation (relatively weak embedding in comparison to peers) all work in favor of independent action over collective action. Appropriate education and experience, and a suitable supply of capital, all work in favor of direct as opposed to indirect action. Thus, we suggest that the influence of social networks on regional industrial employment and renewal is moderated by three kinds of factors - individual characteristics (education, experience and atypical isolation); dyadic tensions (negative relationships); and economic factors (availability of capital) - in the ways that we have elaborated above.

As such, our contribution adds nuance to the claims that having a more qualified, and, perhaps, professionally connected, the workforce can offset large-scale closures (Nyström, 2018) by highlighting the dynamic relationship between embedding in the three types of networks, which complicates the effects of multiple factors within a regional context. Therefore, we argue that although in-depth insights based on individual attributes or single (types of) network influence are useful, it is important to consider how the salience of multiple networks and moderating factors interrelate. As we have shown, such an approach adds the potential to integrate insights, generated through a focus on one type of network or a smaller set of factors (Hane-Weijman, Eriksson \& Henning, 2017; Rodrigues, Guest \& Budjanovcanin, 2016; Uzzi, 1997).

\section{Practical implications}

In addition to the theoretical implications, there are some potential implications for policy and practice. First, there is a need for policymakers to consider how the multiple influences of networks may enable or constraint supportive interventions or lead to particular individual or collective response. For example, there would be little virtue in seeking nontargeted foreign direct investment, if the affected workforce in the region was professionally networked in a field where the demand for employees was stable or rising in other regions. In such circumstances, individuals are likely to be aware and well-connected to be able to take advantage of non-local opportunities that maximize the value of their professional experience. In contrast, programs to support skills development to encourage workforce mobility will not work as effectively as they might, if affected regions are characterized by the strong embedding of individuals in local community networks. Indeed, supporting local entrepreneurial action might be a better option.

Second, our argument can support organizations seeking to downsize responsibly. Potential investments in (potentiating) the social networks of their employees before downsizing may lead to more positive outcomes for individuals and their families, either through stimulating entrepreneurship or enhancing mobility. Where direct employmentenabling network support actions are not easy to conceive, responsibly downsizing organizations may alternatively seek to support or seed local community network developments that maintain the quality of life and meaningful sense of purpose (s) in a locality. By helping communities to remain cohesive, the affected locality might also be assisted in presenting an attractive prospect to external investors looking for a stable workforce likely to offer long-term commitment.

For those affected by closures and layoffs, this paper reinforces the considerable body of literature that emphasizes the importance and utility of social networks at such times - and therefore, the need to invest in those networks' development. In contemporary turbulent 
$\mathrm{OMJ}$

17,1

28

economic times, this, perhaps, includes investing in local community networks as sources of meaning and purpose in any case, as the stability of employment cannot ever be fully guaranteed. However, it also means being aware of the need to invest in professional networks to potentially provide alternative options. We summarize the main policy implications in Table 2. It is, however, important to note, that these suggestions require some levels of criticality and reflection to be effectively implemented. Our intention here is not to provide a panacea or prescription for each kind of possible intervention. Instead, we seek to provide a supportive framework that can help to inform policymaking and encourage responsible management and corporate interventions at times of downsizing and closures.

\section{Limitations, further research and conclusions}

The contribution of this paper - as discussed in the preceding section - has been carefully articulated at the level of broad insights. However, as with any paper, there are necessary limitations to the theoretical breadth that can be encompassed. Thus, while embeddedness as a phenomenon has connections to a range of theoretical concepts - in particular trust, social capital and relationality - entertaining a detailed discussion of any of these topics would expand the argument well beyond the limitations of a single, focused paper. For similar reasons (as well as current theoretical and practical interest), we have focused on one particular kind of conceptual context - industrial closure - while explaining that network influences are present before such crises make them apparent and possibly increase their salience. Thus, while such theoretical topics and alternative contexts have been "bracketed" in the present paper, this presents a range of opportunities for future studies (of a conceptual or empirical nature) that could build on our conceptual work in this paper. We foresee three particular kinds of studies that could usefully be developed.

First, future studies might investigate the relationship between a selected theoretical concept - such as social capital - and effects on individuals' preferred mode of action and preferred unit of action in times of industrial crisis and closure. This could be achieved by focusing on a single type of network embedding to "bracket" some of the possible

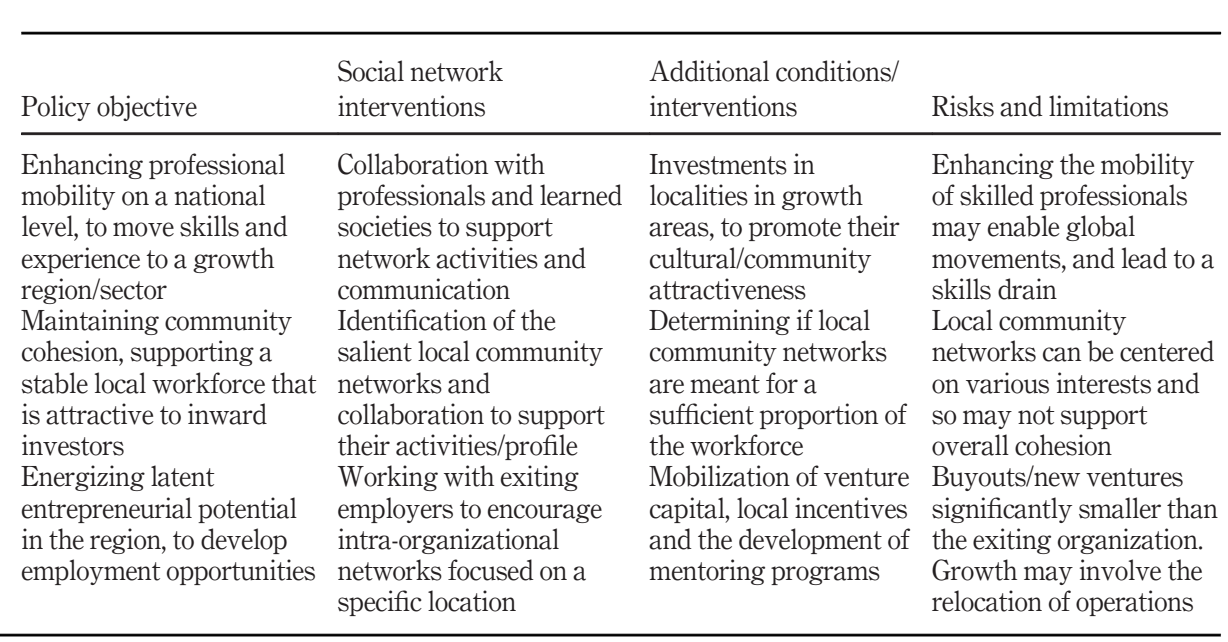

Table 2.

Policy implications arising from embedding in different types of social networks 
complexity at that level, and so allow extensive investigative scope for empirical studies taking a precise focus on the selected concept.

Second, there is scope for empirical research that considers the existence and interaction of social network influences in situations where there is no (obvious) organizational crisis. Researchers might ask how these interaction effects influence vertical and horizontal employment and career shifts in stable times, building on earlier studies, which have tended to focus purely on individual network influences in such conditions.

Third, further empirical research to support the development of the characterization and influence of network types could be considered. We are confident in our characterization of three network types, but further nuances in these characterizations could be important. For example, questions of scale could be considered such as: how does influence vary between national versus international professional networks? Alternatively, more detailed contextual differences may be relevant such as whether local community networks exist in a homogenous or more cosmopolitan regional context (and where, therefore, numbers of self-identified communities and levels of cohesion, may vary).

In conclusion, this paper has developed a theoretical argument for the role of embedding, in different kinds of social networks, as influences on the potential employment-seeking or employment-creating actions of individuals and groups at times of industrial decline and closure. The conclusions drawn are that other things being equal, in such times, namely, embeddedness in intra-organizational networks is likely to favor collective direct action; embeddedness in professional networks is likely to favor individual direct action and embeddedness in community networks is likely to favor individual indirect action. This also contributes to theoretical insights on embedding by identifying how these influences shape the preferred unit of response and mode of response at such times. The discussion has also shown how resource availability, intra- and inter-network tensions and dislocation from (some) networks can have moderating effects on the likely outcomes of network embedding influences. The practical consequences of all of these influences - that may help to shape government policy targeting depressed regions and guide organizations seeking to downsize responsibly have also been briefly considered. We also argue, as elaborated above, that the natural constraints appropriate to the development of our focused paper can be addressed through further opportunities for research examining varied theoretical foci, contextual settings or characterizations of social networks.

\section{References}

Akkerman, A., Born, M., \& Torenvlied, R. (2013). Solidarity, strikes, and scabs: How participation norms affect union members' willingness to strike. Work and Occupations, 40(3), 250-280, doi: $10.1177 / 0730888413481481$.

Andersen, K. V. (2013). The problem of embeddedness revisited: Collaboration and market types. Research Policy, 42(1), 139-148, doi: 10.1016/j.respol.2012.05.005.

Andrews, R., Boyne, G. A., Meier, K. J., O’Toole, L. J., \& Walker, R. M. (2011). Environmental and organizational determinants of external networking. The American Review of Public Administration, 41(4), 355-374, doi: 10.1177/0275074010382036.

Anteby, M., Chan, C. K., \& DiBenigno, J. (2016). Three lenses on occupations and professions in organizations: Becoming, doing, and relating. The Academy of Management Annals, 10(1), 183244, doi: 10.1080/19416520.2016.1120962.

Arntz, M., Gregory, T., \& Zierahn, U. (2016). The risk of automation for jobs in OECD countries: A comparative analysis (no. 189), OECD Publishing website, Retrieved from http://dx.doi.org/ 10.1787/5jlz9h56dvq7-en 
OMJ 17,1

Ashforth, B. E., \& Reingen, P. H. (2014). Functions of dysfunction: Managing the dynamics of an organizational duality in a natural food cooperative. Administrative Science Quarterly, 9(3), 474516, doi: 10.1177/0001839214537811.

Avnimelech, G., \& Feldman, M. (2010). Regional corporate spawning and the role of homegrown companies. Review of Policy Research, 27(4), 475-489, doi: 10.1111/j.1541-1338.2010.00452.x.

Bacon, N., Wright, M., \& Demina, N. (2004). Management buyouts and human resource management. British Journal of Industrial Relations, 42(2), 325-347.

Bailey, D., Chapain, C., \& de Ruyter, A. (2012). Employment outcomes and plant closure in a postindustrial city: An analysis of the labor market status of MG Rover workers three years on. Urban Studies, 49(7), 1595-1612, doi: 10.1177/0042098011415438.

Bathelt, H., Malmberg, A., \& Maskell, P. (2004). Clusters and knowledge: Local buzz, global pipelines and the process of knowledge creation. Progress in Human Geography, 28(1), 31-56, doi: 10.1191/0309132504ph469oa.

Batjargal, B. (2003). Social Capital and entrepreneurial performance in Russia: A longitudinal study. Organization Studies, 24(4), 535-556, doi: 10.1177/0170840603024004002.

Battilana, J. (2006), “Agency and institutions: the enabling role of individuals' social position", Organization, 13(5), pp. 653-676, doi: 10.1177/1350508406067008.

Benneworth, P. (2004). In what sense 'regional development?': Entrepreneurship, underdevelopment and strong tradition in the periphery. Entrepreneurship and Regional Development, 16(6), 439-458, doi: 10.1080/0898562042000249786.

Berends, H., van Burg, E., \& van Raaij, E. M. (2010). Contacts and contracts: Cross-level network dynamics in the development of an aircraft material. Organization Science, 22(4), 940-960, doi: 10.1287/orsc.1100.0578.

Bentley, G., Bailey, D., \& De Ruyter, A. (2010), "The MG Rover closure and policy response: an evaluation of the task force model in the UK", International Journal of Automotive Technology and Management, 10(2/3), p. 236, doi: 10.1504/IJATM.2010.032626.

Biniari, M. G. (2012). The emotional embeddedness of corporate entrepreneurship: The case of envy. Entrepreneurship Theory and Practice, 36(1), 141-170, doi: 10.1111/j.1540-6520.2010.00437.x.

Boschma, R., \& Lambooy, J. (1999), "The prospects of an adjustment policy based on collective learning in old industrial regions", Geo Journal, 49(4), pp. 391-399, doi: 10.1023/A:1007144414006.

Burby, R. J. (2003). Making plans that matter: Citizen involvement and government action. Journal of the American Planning Association, 69(1), 33-49, doi: 10.1080/01944360308976292.

Chajewski, L. (2007), “Agency relationships, embeddedness and employment relations”, Current Sociology, 55(1), pp. 24-40, doi: 10.1177/0011392107070132.

Ciabuschi, F., Dellestrand, H., \& Martín, O. M. (2011). Internal embeddedness, headquarters involvement, and innovation importance in multinational enterprises. Journal of Management Studies, 48(7), 1612-1639, doi: 10.1111/j.1467-6486.2011.01014.x.

Clark, E. (2004). Power, action and constraint in strategic management: Explaining enterprise restructuring in the Czech Republic. Organization Studies, 25(4), 607-627, doi: 10.1177/ 0170840604042403.

Collinson, S. C., \& Wang, R. (2012). The evolution of innovation capability in multinational enterprise subsidiaries: Dual network embeddedness and the divergence of subsidiary specialization in Taiwan. Research Policy, 41(9), 1501-1518, doi: 10.1016/j.respol.2012.05.007.

Crossley, C. D., Bennett, R. J., Jex, S. M., \& Burnfield, J. L. (2007). Development of a global measure of job embeddedness and integration into a traditional model of voluntary turnover. Journal of Applied Psychology, 92(4), 1031-1042, doi: 10.1037/0021-9010.92.4.1031.

Dany, F., Louvel, S., \& Valette, A. (2011). Academic careers: The limits of the 'boundaryless approach' and the power of promotion scripts. Human Relations, 64(7), 971-996, doi: 10.1177/ 0018726710393537. 
Datta, D. K., Guthrie, J. P., Basuil, D., \& Pandey, A. (2010). Causes and effects of employee downsizing: A review and synthesis. Journal of Management, 36(1), 281-348, doi: 10.1177/ 0149206309346735.

Davis, M. A. (2003). Factors related to bridge employment participation among private sector early retirees. Journal of Vocational Behavior, 63(1), 55-71, doi: 10.1016/S0001-8791(02)00016-7.

Davis, A., Renzulli, L., \& Aldrich, H. (2006). Mixing or matching? The influence of voluntary associations on the occupational diversity and density of small business owners' networks. Work and Occupations, 33(1), 42-72, doi: 10.1177/0730888405281914.

Delgado-Márquez, B. L., Hurtado-Torres, N. E., Pedauga, L. E., \& Cordón-Pozo, E. (2018). A network view of innovation performance for multinational corporation subsidiaries. Regional Studies, 52(1), 47-67, doi: 10.1080/00343404.2016.1272756.

Engeström, Y. (2006). From well-bounded ethnographies to intervening in mycorrhizae activities. Organization Studies, 27(12), 1783-1793.

Feldman, D. C., \& Ng, T. W. H. (2007). Careers: mobility, embeddedness, and success. Journal of Management, 33(3), 350-377, doi: 10.1177/0149206307300815.

Felps, W., Mitchell, T. R., Hekman, D. R., Lee, T. W., Holtom, B. C., \& Harman, W. S. (2009). Turnover contagion: How coworkers' job embeddedness and job search behaviors influence quitting. Academy of Management Journal, 52(3), 545-561, doi: 10.5465/ AMJ.2009.41331075.

Fletcher, J., \& Bailyn, L. (1996). Challenging the last boundary: Reconnecting work and family, in Arthur, M.B., \& Rousseau, D.M. (Eds), The Boundaryless Career: A New Employment Principle for a New Organizational Era (pp. 256-267). Oxford: Oxford University Press.

Frenkel, S. J. (2003). The embedded character of workplace relations. Work and Occupations, 30(2), 135-153, doi: 10.1177/0730888403251516.

Gardiner, J., Stuart, M., MacKenzie, R., Forde, C., Greenwood, I., \& Perrett, R. (2009). Redundancy is a critical life event moving on from the Welsh steel industry through career change. Work, Employment and Society, 23(4), 727-745, doi: 10.1177/0950017009344917.

Geletkanycz, M. A., \& Boyd, B. K. (2011). CEO outside directorships and firm performance: A reconciliation of agency and embeddedness views. Academy of Management Journal, 54(2), 335-352, doi: 10.5465/AMJ.2011.60263094.

Granovetter, M. (1985), "Economic action and social structure: the problem of embeddedness", American Journal of Sociology, 91(3), pp. 481-510.

Granovetter, M. S. (1973). The strength of weak ties. American Journal of Sociology, 78(6), 1360-1380, doi: $10.1086 / 225469$.

Hane-Weijman, E., Eriksson, R. H., \& Henning, M. (2017). Returning to work: Regional determinants of re-employment after major redundancies. Regional Studies, 52(6), 768-780, doi: 10.1080/00343404.2017.1395006.

Hartley, S. (2017), The Fuzzy and the Techie: Why the Liberal Arts Will Rule the Digital World, Reprint edition, S.1.. Boston, MA: Mariner Books.

Hassink, R., \& Shin, D. -H. (2005). The restructuring of old industrial areas in Europe and Asia. Environment and Planning A: Economy and Space, 37(4), 571-580.

Hayton, J. C., Carnabuci, G., \& Eisenberger, R. (2012). With a little help from my colleagues: A social embeddedness approach to perceived organizational support. Journal of Organizational Behavior, 33(2), 235-249, doi: 10.1002/job.755.

Hess, M. (2004). Spatial' relationships? Towards a reconceptualization of embeddedness. Progress in Human Geography, 28(2), 165-186, doi: 10.1191/0309132504ph479oa.

Hochner, A., \& Granrose, C. S. (1985). Sources of motivation to choose employee ownership as an alternative to job loss. Academy of Management Journal, 28(4), 860-875, doi: 10.2307/256241. 
Howes, L. M., \& Goodman-Delahunty, J. (2014). Predicting career stability and mobility embeddedness and boundarylessness. Journal of Career Development, 42(3), 244-259, doi: 10.1177/0894845314548722.

Hsiao, R. -L., Tsai, S. D. -H., \& Lee, C. -F. (2006). The problems of embeddedness: Knowledge transfer, coordination and reuse in information systems. Organization Studies, 27(9), 1289-1317, doi: $10.1177 / 0170840606064108$.

Husted, K., \& Michailova, S. (2010). Dual allegiance and knowledge sharing in inter-firm R\&D collaborations. Organizational Dynamics, 39(1), 37-47, doi: 10.1016/j.orgdyn.2009.10.004.

Ituma, A., \& Simpson, R. (2009). The 'boundaryless' career and career boundaries: Applying an institutionalist perspective to ICT workers in the context of Nigeria. Human Relations, 62(5), 727-761, doi: 10.1177/0018726709103456.

Jack, S., \& Anderson, A. (2002). The effects of embeddedness on the entrepreneurial process. Journal of Business Venturing, 17(5), 467-487, doi: 10.1016/S0883-9026(01)00076-3.

Jaumier, S. (2016). Preventing chiefs from being chiefs: An ethnography of a co-operative sheet-metal factory. Organization, 24(2), 218-239, doi: 10.1177/1350508416664144.

Kalantaridis, C., \& Bika, Z. (2006). In-migrant entrepreneurship in rural England: Beyond local embeddedness. Entrepreneurship and Regional Development, 18(2), 109-131, doi: 10.1080/ 08985620500510174.

Kelley, D.J., Peters, L., \& O'Connor, G. C. (2009). Intra-organizational networking for innovation-based corporate entrepreneurship. Journal of Business Venturing, 24(3), 221-235, doi: 10.1016/j. jbusvent.2008.05.010.

Kilduff, M., \& Brass, D. J. (2010). Organizational social network research: Core ideas and key debates. The Academy of Management Annals, 4(1), 317-357, doi: 10.1080/19416520.2010.494827.

Kim, P.H., Aldrich, H.E., \& Keister, L.A. (2006). Access (not) denied: The impact of financial, human, and cultural capital on entrepreneurial entry in the United States. Small Business Economics, 27(1), 5-22, doi: 10.1007/s11187-006-0007-x.

Kistruck, G. M., \& Beamish, P. W. (2010). The interplay of form, structure, and embeddedness in social intrapreneurship. Entrepreneurship Theory and Practice, 34(4), 735-761, doi: 10.1111/ j.1540-6520.2010.00371.x.

Labianca, G., \& Brass, D. J. (2006). Exploring the social ledger: Negative relationships and negative asymmetry in social networks in organizations. Academy of Management Review, 31(3), 596-614, doi: 10.5465/AMR.2006.21318920.

Lawrence, B. S. (2011). Careers, social context and interdisciplinary thinking. Human elations, 64(1), 59-84.

Lawrence, T. B., Hardy, C., \& Phillips, N. (2002). Institutional effects of inter-organizational collaboration: The emergence of proto-institutions. Academy of Management Journal, 45(1), 281-290, doi: 10.2307/3069297.

Lee, J., \& Kim, S. (2011). Exploring the role of social networks in affective organizational commitment: Network centrality, the strength of ties, and structural holes. The American Review of Public Administration, 41(2), 205-223, doi: 10.1177/0275074010373803.

Lepak, D. P., Smith, K. G., \& Taylor, M. S. (2007). Value creation and value capture: A multilevel perspective. Academy of Management Review, 32(1), 180-194, doi: 10.5465/AMR.2007.23464011.

Leppäaho, T., Chetty, S. and Dimitratos, P. (2018), "Network embeddedness in the internationalization of biotechnology entrepreneurs", Entrepreneurship \& Regional Development, 30(5/6), 562-584, doi: 10.1080/08985626.2017.1408697.

Levin, D., \& Cross, R. (2004). The strength of weak ties you can trust: The mediating role of trust in effective knowledge transfer. Management Science, 50(11), 1477-1490.

Levin, D., Walter, J., \& Murnighan, J. (2011). The power of reconnection-how dormant ties can surprise you. MIT Sloan Management Review, 52(3), 45-50. 
Lin, N., Ensel, W. M., \& Vaughn, J. C. (1981). Social resources and strength of ties: Structural factors in occupational status attainment. American Sociological Review, 46(4), 393-405, doi: 10.2307/ 2095260.

Lo, K. I. H., Wong, I. A., Yam, C. M. R., \& Whitfield, R. (2012). Examining the impacts of community and organization embeddedness on self-initiated expatriates: The moderating role of expatriatedominated private sector. The International Journal of Human Resource Management, 23(20), 4211-4230, doi: 10.1080/09585192.2012.665075.

Lowe, N., Hagan, J., \& Iskander, N. (2010). Revealing talent: Informal skills intermediation as an

Social network influences on employee emergent pathway to immigrant labor market incorporation. Environment and Planning A: Economy and Space, 42(1), 205-222, doi: 10.1068/a4238.

MacKenzie, R., Stuart, M., Forde, C., Greenwood, I., Gardiner, J., \& Perrett, R. (2006). All that is solid?': Class, identity and the maintenance of a collective orientation amongst redundant steelworkers. Sociology, 4O(5), 833-852, doi: 10.1177/0038038506067509.

Maertz, C. P., \& Griffeth, R. W. (2004). Eight motivational forces and voluntary turnover: A theoretical synthesis with implications for research. Journal of Management, 30(5), 667-683.

Manning, S. (2010). The strategic formation of project networks: A relational practice perspective. Human Relations, 63(4), 551-573.

Minchin, T. (2009), "It knocked this city to its knees': the closure of Pillowtex Mills in Kannapolis, North Carolina and the decline of the US textile industry", Labor History, 50(3), pp. 287-311, doi: $10.1080 / 00236560903020906$.

Mitchell, T. R., Holtom, B. C., Lee, T. W., Sablynski, C. J., \& Erez, M. (2001). Why people stay: Using job embeddedness to predict voluntary turnover. Academy of Management Journal, 44(6), 1102-1121, doi: 10.2307/3069391.

Mohrman, S. A., Tenkasi, R. V., \& Mohrman, A. M. (2003). The role of networks in fundamental organizational change. A grounded analysis. The Journal of Applied Behavioral Science, 39(3), 301-323, doi: 10.1177/0021886303258072.

Moran, P. (2005). Structural vs relational embeddedness: Social capital and managerial performance. Strategic Management Journal, 26(12), 1129-1151, doi: 10.1002/smj.486.

Murphy, W. M., Burton, J. P., Henagan, S. C., \& Briscoe, J. P. (2013). Employee reactions to job insecurity in a declining economy. Group and Organization Management, 38(4), 512-537, doi: 10.1177/ 1059601113495313.

Murray, R., Baldwin, J., Ridgway, K., \& Winder, B. (2005). Socio-economic decline and adaptation: South Yorkshire's former coalfields. Local Economy: The Journal of the Local Economy Policy Unit, 20(4), 344-359, doi: 10.1080/02690940500286552.

Ng, T. W. H., \& Feldman, D. C. (2012). The effects of organizational and community embeddedness on work-to-family and family-to-work conflict. Journal of Applied Psychology, 97(6), 1233-1251, doi: $10.1037 / \mathrm{a} 0029089$.

Nyström, K. (2018). Regional resilience to displacements. Regional Studies, 52(1), 4-22, doi: 10.1080/ 00343404.2016.1262944.

Parrilli, M. D. (2009). Collective efficiency, policy inducement and social embeddedness: Drivers for the development of industrial districts. Entrepreneurship and Regional Development, 21(1), 1-24, doi: $10.1080 / 08985620801886513$.

Parry, J. (2003). The changing meaning of work: Restructuring in the former coalmining communities of the South Wales valleys. Work, Employment and Society, 17(2), 227-246, doi: 10.1177/ 0950017003017002001.

Porac, J., Thomas, H., \& Badden-Fuller, C. (2011). Competitive groups as cognitive communities: The case of Scottish knitwear manufacturers revisited. Journal of Management Studies, 48(3), 646-664.

Powell, W. W. (1990). Neither market nor hierarchy: Network forms of organization. Research in Organizational Behavior, 12, 295-336. 
Provan, K. G., Huang, K., \& Milward, H. B. (2009). The evolution of structural embeddedness and organizational social outcomes in a centrally governed health and human services network. Journal of Public Administration Research and Theory, 19(4), 873-893, doi: 10.1093/jopart/ mun036.

Rodrigues, R., \& Guest, D. (2010). Have careers become boundaryless?. Human Relations, 63(8), 1157-1175, doi: 10.1177/0018726709354344.

Rodrigues, R., Guest, D., \& Budjanovcanin, A. (2016). Bounded or boundaryless? An empirical investigation of career boundaries and boundary-crossing. Work, Employment and Society, 30(4), 669-686, doi: 10.1177/0950017015570726.

Roos, A. (2018). Embeddedness in context: Understanding gender in a female entrepreneurship network. Entrepreneurship and Regional Development, 1-14, doi: 10.1080/08985626.2018.1551793.

Savage, L. (2004). Public sector unions shaping hospital privatization: The creation of Boston medical center. Environment and Planning A: Economy and Space, 36(3), 547-568, doi: 10.1068/a34172.

Smith, B. R., \& Stevens, C. E. (2010). Different types of social entrepreneurship: The role of geography and embeddedness on the measurement and scaling of social value. Entrepreneurship and Regional Development, 22(6), 575-598, doi: 10.1080/08985626.2010.488405.

Staber, U. (2011). Partners forever? An empirical study of relational ties in two small-firm clusters. Urban Studies, 48(2), 235-252, doi: 10.1177/0042098009360679.

Stam, E. (2007), "Why butterflies don't leave: locational behavior of entrepreneurial firms", International Journal Economic Geography, 83(1), pp. 27-50, doi: 10.1111/j.1944-8287.2007. tb00332.x.

Strangleman, T. (2001). Networks, place and identities in post-industrial mining communities. International Journal of Urban and Regional Research, 25(2), 253-267, doi: 10.1111/14682427.00310 .

Sydow, J., Lindkvist, L., \& DeFillippi, R. (2004). Project-based organizations, embeddedness and repositories of knowledge: Editorial. Organization Studies, 25(9), 1475-1489, doi: 10.1177/ 0170840604048162.

Tasselli, S. (2015). Social networks and inter-professional knowledge transfer: The case of healthcare professionals. Organization Studies, 36(7), 841-872, doi: 10.1177/0170840614556917.

Tomaney, J., Pike, A., \& Cornford, J. (1999). Plant closure and the local economy: The case of swan hunter on Tyneside. Regional Studies, 33(5), 401-411, doi: 10.1080/00343409950081257.

Uzzi, B. (1997). Social structure and competition in interfirm networks: The paradox of embeddedness. Administrative Science Quarterly, 42(1), 35-67, doi: 10.2307/2393808.

Valcour, M., Bailyn, L., and Quijada, M. (2007). Customized careers, in Gunz, H., \& Maury, P. (Eds), Handbook of Career Studies (pp. 188-210). Thousand Oaks, CA: SAGE publications, Retrieved from http://sk.sagepub.com/reference/hdbk_career/n11.xml

Valette, A., \& Culié, J. -D. (2015). Career scripts in clusters: A social position approach. Human Relations, 68(11), 1745-1767, doi: 10.1177/0018726715569515.

van Rijnsoever, F .J., Hessels, L. K., \& Vandeberg, R. L. J. (2008). A resource-based view on the interactions of university researchers. Research Policy, 37(8), 1255-1266, doi: 10.1016/j. respol.2008.04.020.

Villadsen, A. R. (2011). Structural embeddedness of political top executives as the explanation of policy isomorphism. Journal of Public Administration Research and Theory, 21(4), 573-599, doi: 10.1093/jopart/mur007.

Vollan, B. (2012). Pitfalls of externally initiated collective action: A case study from South Africa. World Development, 40(4), 758-770, doi: 10.1016/j.worlddev.2011.09.016.

von Nordenflycht, A. (2010). What is a professional service firm? Toward a theory and taxonomy of knowledge-intensive firms. Academy of Management Review, 35(1), 155-174. 
Wang, C. L., \& Altinay, L. (2012). Social embeddedness, entrepreneurial orientation and firm growth in ethnic minority small businesses in the UK. International Small Business Journal: Researching Entrepreneurship, 30(1), 3-23, doi: 10.1177/0266242610366060.

Whitaker, A. (1986), "Managerial strategy and industrial relations: a case study of plant relocation", Journal of Management Studies, 23(6), 657-687, doi: 10.1111/j.1467-6486.1986.tb00441.x.

Whitehurst, F., \& Siedlok, F. (2006). From closure to excellence: Micro-clusters, local embeddedness and public policy. Presented at the 29th Institute for Small Business and Entrepreneurship Conference, Cardiff.

Social network influences on employee

Whitehurst, F., Siedlok, F., \& Race, J. (2008). Reach-in and reach-out: The story of the MSc in Pipeline engineering at Newcastle University. International Small Business Journal: Researching Entrepreneurship, 26(6), 709-733, doi: 10.1177/0266242608096090.

Wright, M., Hoskisson, R. E., \& Busenitz, L. W. (2001). Firm rebirth: Buyouts as facilitators of strategic growth and entrepreneurship. Academy of Management Perspectives, 15(1), 111-125, doi: 10.5465/AME.2001.4251486.

Zhang, J. (2010). The problems of using social networks in entrepreneurial resource acquisition. International Small Business Journal, 28, 338-361.

Zissimopoulos, J. M., \& Karoly, L. A. (2007). Transitions to self-employment at older ages: The role of wealth, health, health insurance and other factors. Labour Economics, 14(2), 269-295, doi: 10.1016/j.labeco.2005.08.002.

\section{Corresponding author}

Frank Siedlok can be contacted at: f.siedlok@auckland.ac.nz

For instructions on how to order reprints of this article, please visit our website: 